\title{
"Seeds Must be Among the Greatest Travelers of All:" Native American Literatures Planting the Seeds for a Cosmopolitical Environmental Justice Discourse
}

Political reality in so many places still operates on terms and conceptualizations determined by colonial languages and corresponding mindsets: nature, wilderness, sacrifice zone, sustainability. Social critics talk about social and political change, but a fundamental factor for such development is changing terminology to reform the status quo in Western ways of thinking. Scholars in the Environmental Humanities and Indigenous Studies are working toward a paradigm shift by exploring confluences between Western and Indigenous sciences and seeking concepts and terms that contribute to a more inclusive intellectual framework. In recent years, the concept of cosmopolitics, coined by science philosopher Isabelle Stengers, has helped to focus these efforts, and Joni Adamson's work has been crucial for an inclusion of cosmopolitics into ecocritical discourse, especially environmental justice ecocriticism. In acknowledgement of pluralism beyond human cultures, cosmopolitics is a theoretical framework and political strategy for an expansion of political participation beyond the human realm. It integrates environmental and ecological justice with a strong focus on social interaction, which also corresponds to the philosophies guiding Indigenous movements. If the term helps scholars pinpoint and explain the common denominators of existing political strategies, it may be a useful term and concept for those in the political arena. Here, I consider where, how, and why the term could be introduced into the political discourse to enhance communication. Indeed, both environmental justice theory and Indigenous literatures point in the direction that cosmopolitics may find fruitful ground in the political discourse of transnational movements that include environmental justice as one of many concerns, rather than in national movements that may be narrower in scope. 
Native American literatures creatively contribute to a more inclusive and expansive notion of environmental and ecological justice and to a decolonization of thought and speech. In Gardens in the Dunes (1999), for instance, Leslie Marmon Silko indicates the necessity of changed concepts and practices that lead to a more successful communication, one that negotiates multicultural and multispecies experiences. Silko's critique of Euro-American imperialism of 1900 parallels current criticism of neoliberal globalization, incorporates key features of environmental justice and portrays strategies that are realistic and timely. Her emphasis on female leadership reflects the fundamental role women activists have played within the environmental justice movement nationally and worldwide. Silko emphasizes a renewed spirituality and philosophy that reconnects humans to non-human players and relativizes cultural difference by considering interspecies dynamics. Indigenous activists tend to stress the spiritual component of environmental justice struggles and the land-based philosophy and application of Native science. Thus, cross-reading Silko's novel with studies about environmental justice organizing, I argue that women activists' intercultural networking provides a fruitful ground for the cosmopolitics concept, especially in regards to mindful material and knowledge exchange, acceptance of cultural syncretism, and consideration of spirituality. However, introducing "cosmopolitics" and the concept behind it into the political arena also requires more effort of scholars to educate the public about how theoretical frameworks of existing political strategies can be addressed, explained, and better negotiated.

Indigenous Cosmopolitics and Global Environmental Justice Movements With keen observations and complex ideas developing from Alexander von Humboldt via Franz Boas and Gregory Bateson to Isabelle Stengers and Bruno Latour, the concept of cosmopolitics 
has a rich history (Gemein 150-183 and Adamson, "Source of Life" 253-256). When Stengers coined the term "cosmopolitics," she synthesized multiple scientific explorations. Most importantly for this analysis, the concept builds on critical anthropological thought about multinaturalism - the co-existence of multiple realities or worlds — as expressed in Eduardo Viveiros de Castro's work on Amerindian ontologies. Amazonian cosmologies indicate a nondifferentiation between the internal forms of humans and nonhuman beings because they were all human originally and later changed their only corporeal forms. The consequence of "a spiritual unity and a corporeal diversity" is that for Amerindians, "culture or the subject is the form of the universal, while nature or the object is the form of the particular" (Viveiros de Castro 466). Viveiros de Castro's research has thus initiated a reconsideration of political concepts, e.g. cosmopolitanism, which rely on multicultural ontologies but do not acknowledge the possibility of multiple realities or multinaturalism.

As literary critic Ursula Heise discusses in Sense of Place and Sense of Planet (2008), the concept of cosmopolitanism has been recuperated to address the increasing experience of transnational connectedness in regards to identity formation and environmental consciousness. She develops the notion of an "eco-cosmopolitanism, or environmental world citizenship" (10) as a response to a frequently less local and more "systemic sense of a planet" (56). Moreover, Heise's eco-cosmopolitan vision addresses the question of rights of "nonhuman parts of the biosphere" and acknowledges the "connectedness with both animate and inanimate networks of influence and exchange" (61). However, she maintains human cultural lenses as a divergent, yet explicitly anthropocentric approach. In contrast, science sociologist Bruno Latour integrates Viveiros de Castro's more expansive notion of ontological differences into his own vision of a "political ecology" that could re-unite the natural and the political realm after centuries of 
culture-nature distinctions (Politics of Nature 3). Latour calls for a simultaneous preoccupation "with the sciences, with natures, and with politics, in the plural" (ib.) and for a democracy that is "extended to nonhumans" (223) and thus also would require new terminology. He promotes cosmopolitics as a better choice than cosmopolitanism, explaining: "Cosmopolitans may dream of the time when citizens of the world come to recognize that they all inhabit the same world, but cosmopolitics is up against a somewhat more daunting task: to see how this 'same world' can be slowly composed" (Latour, "Whose Cosmos" 457; emphasis in original), i.e. composed out of a multitude of ontologies and epistemologies.

Simultaneously, Stengers has developed the term "cosmopolitical" out of the familiar term "cosmopolitan." The new composite stresses not just cultural pluralism but multinatural conditions, meaning that "cosmos" has to be "distinguished here from any particular cosmos, or world, as a particular tradition may conceive of it" and is "constituted by these multiple, divergent worlds" (995). The term "politics," in turn, refers to "putting science into politics" in order to deal with the matters of who can speak for whom and represent what (ib.), which fundamentally changes the treatment of justice issues. While cosmopolitics may not fully solve the anthropocentric limitations of (eco-)cosmopolitanism, it allows for more complexity in thought, action, and legal-political representation. It acknowledges that one may deal with the same biosphere, but with different material realities, whether or not one shares the same cultural lens. In this article, I adhere to Latour and Stengers' definition of cosmopolitics and argue that for a practical manifestation, the term itself needs to become part of the political, especially environmental justice discourse.

Since the 2010s, Adamson has repeatedly discussed the concept of cosmopolitics, its history and its close relation to Indigenous ontologies, and she has convincingly argued that while 
environmental and ecological justice and cosmopolitics may be recent phenomena in Western thought, they have been an integral part of Indigenous resistance against colonization for hundreds of years (Adamson, "Indigenous Literatures," "Source of Life" and "Cosmovisions"). Within tribal ontologies, community exceeds the "humans-only" perspective and there is little conceptual difference between ecological and environmental justice. Vine Deloria Jr. stresses this relational nature of socio-political existence: "In the moral universe all activities, events, and entities are related, and consequently it does not matter what kind of existence an entity enjoys, for the responsibility is always there for it to participate in the continuing creation of reality" (47). While Indigenous communities have their own, culturally specific terms, concepts and definitions, the concept behind the scholarly neologism "cosmopolitics" corresponds to some common denominators of Indigenous philosophies. Thus Adamson and Marisol de la Cadena have built on Viveiros de Castro's research as well as Latour and Stenger's explorations by applying cosmopolitics as a descriptive and explanatory term for tenets of Indigenous philosophies that drive Indigenous organizing (Adamson, "Indigenous Literatures, Multinaturalism, and Avatar" 148-150). For instance, Adamson discusses Heise's ecocosmopolitan proposal and call for "environmental justice fieldwork" (Heise 159) with regards to explorations of Indigenous cosmopolitics (Adamson, "Indigenous Literatures, Multinaturalism, and Avatar" 147 and "Cosmovisions" 259-260). Adamson examines the Zapatista phrase "¡Todos Somos Indios!" as an example of alternative conceptualizations of indigeneity and inclusive, transnational movements that feature Indigenous leadership and cosmopolitical strategies in response to neoliberal globalization ("iTodos Somos Indios!" 5-6). Yet Indigenous approaches vary, as Sarah Jaquette Ray shows in her analysis of Indigenous unease with all too transnational and inclusive collaboration, identifying a fear of losing specificity and becoming 
vulnerable to exploitation, for instance through cultural appropriation (Ray 6-8). Ray thus outlines a pronounced "local/global dialectic" (3). Communities and movements use political strategies situationally and at times synchronously. Nevertheless, as Adamson has emphasized repeatedly, multinaturalism and cosmopolitics as theoretical framework have a long history in Indigenous activism.

Similarly, de la Cadena argues that the Bolivian Ley (Corta) de los Derechos de la Madre Tierra of 2010 and the appearance of "sentient entities, known as tirakuna, or earth-beings" (de la Cadena 341)—for instance a sentient mountain with likes, dislikes, and rights—in sociopolitical protests do not reflect a paradigm shift by definition. Rather, Indigenous cosmopolitical perspectives that have always been present are now becoming politically and globally visible (348-349). Visibility also arises from the growing body of Native American publications, some of which effectively mediate cosmopolitical ideas as I have discussed in "Multispecies Thinking from Alexander von Humboldt to Leslie Marmon Silko." Chickasaw author Linda Hogan, for instance, focuses her work on the concept of "terrestrial intelligence" (Hogan 11) and non-human agency, meaning the ability of an entity or being to act and make choices. The concept of earthbeings and the notion of terrestrial intelligence transcend the nature-culture dualism common in Western cultures. Since cosmopolitics allows for human and non-human participants, it is fundamentally relational—a key feature of Indigenous paradigms. Yuchi-Muscogee scholar Daniel Wildcat encourages Indigenous peoples to "demonstrate their ancient democratic traditions" that define "democracy as life-enhancing ecological practices" (63), treating environmental surroundings as "relatives, not resources" (64). Relational ontologies with their inherent acknowledgment of the rights of complex non-human entities and their focus on community rights — in contrast to the liberal rights focus on the individual — have continuously 
been expressed in Indigenous common law and to some degree in contemporary tribal and national law. Cosmopolitics explains phenomena all over the world that recognize the nonhuman environment within the realm of rights-bearing entities, be it the above mentioned Bolivian law, the "rights of nature" provisions developed with the assistance of the Community Environmental Legal Defense Fund for Ecuador's 2008 Constitution, the designation of the Whanganui River in New Zealand as a legal person in 2012, or the designation of dolphins as non-human persons, albeit not legal persons, in India in 2013. While the new Bolivian law, for instance, does not necessitate the concept of personhood for legal representation, the concept is often used to bridge more complex understandings of rights-bearing entities and the conceptualization of the individual human being that has long been at the core of justice theory and (inter)national law.

The phenomena can be better understood and connected to existing discourses if cosmopolitics as a tool for explanation and description finds its way into political communication, where it may enhance what de la Cadena calls an "ontological pluralization of politics" (360). Yet while the phenomenon of cosmopolitical practice has been discussed widely, the term "cosmopolitics" is mostly used by scholars only. Thus my goal is to explore where, how, and why the term could be introduced into the political discourse to clarify and disseminate a theoretical framework that has long been manifested in Indigenous movements, albeit in culturally diverse ways and under various terms and definitions. If the term is helpful for scholarly analysis, it may be helpful for those in the trenches of political action.

Moreover, cosmopolitics may not pose such an intellectual challenge to environmental justice activists, especially since gender appears to be a factor in overcoming the patriarchal legacy of neoliberalism. Environmental justice struggles are largely carried and led by women 
who, according to Diane-Michelle Prindeville, are "less vested in the status quo than men, less convinced by the arguments presented to them by authorities, and more committed to their own visions" (4). It is further promising that the movement has integrated a high sensibility for diversity and case-specific parameters; it displays a plurality of justice definitions, which is slowly breaking the ideological patterns of mainstream capitalist discourse and neoliberalism. However, American environmental justice discourse is preoccupied with the aspect of distributional equity and thus limited in scope, while transnational movements integrate environmental justice and ecological justice into larger sets of concerns (Schlosberg 46, 51). In resistance to the practices of neoliberal institutions such as the World Trade Organization or the World Bank, these transnational movements also ascribe a greater significance to recognition (in reference to status and/or cultural identity), community functioning (as in well-being and resilience) and participation in decision-making processes and procedural justice in addition to distributional equity (82-95). These four aspects indicate that where community knowledge and decision-making processes are honored and self-determination can be pursued, integrative discourses, studies, and negotiations can be held. They also are key factors for cosmopolitical practice as it de-emphasizes colonial concepts of identity politics and political sovereignty (de la Cadena 345,360 ) by prioritizing self-determination, intellectual sovereignty, and alliances. Cosmopolitics aims at sustaining life in its cultural and biological diversity to enhance overall resilience, which correlates with David Schlosberg's analysis of pluralistic understandings of justice in Defining Environmental Justice (2007). Schlosberg ascribes more experience with plurality, multiple justice understandings, and interrelated key factors to transnational movements. People engaged in these movements might thus find the term "cosmopolitics" and the concept behind it most effective. 
Planting the Seeds of Global Cosmopolitics in Silko's Gardens in the Dunes

Indigenous people have repeatedly called for a change of language, and thus ways of thinking, in mainstream discourses. In Red Alert! Saving the Planet with Indigenous Knowledge (2009), Wildcat suggests: "In order to acquire insights into how to live well in the diverse environments of this planet, humankind needs multigenerational deep spatial knowledges as well as scientific knowledge and its application in increasingly powerful technologies" (15-16). Since contemporary authors creatively integrate oral tradition and Indigenous knowledge into their publications, Adamson concludes that "cultural and literary critics should treat multicultural literatures not only as literary work but as theoretical work" (American Indian Literature 96-97). Therefore, these works educate, inspire, and can serve as seeds of change on a very pragmatic level of individual thought and action, which also contributes to an overall change of discourse. Silko's Gardens in the Dunes, for instance, illustrates Indigenous cosmopolitics, promotes the decolonization of the mind and challenges current environmental justice discourses. As the following analysis will show, it incorporates environmental justice key features, reflects the current organizational structures within the environmental justice movement, and explains Indigenous perspectives on the significance of spirituality for the sake of a cosmopolitical paradigm change.

Silko tells the stories of two orphaned sisters of the Sand Lizard people, a fictional tribe inspired by O'odham and Colorado River peoples. The older, Sister Salt, remains in the Southwest, witnessing reservation life, canal construction, and allotment. The younger, elevenyear-old Indigo, is taken on a voyage to Europe, visiting women with whom she forges alliances based on multi-layered spiritual and cultural similarities. The plot is set in the year 1900, a high 
water mark in American global imperialism and the assimilation era of federal Indian policy. Silko addresses land loss, corporate-driven biopiracy, commercialization of sacred artifacts, ongoing slavery, abuse and poverty, confinement to Indian agencies, life on allotted reservation land as well as in cities and off-reservation boarding schools, Native language suppression, and lack of civil rights, citizenship, and religious freedom.

The novel especially illustrates a key concern Schlosberg has identified for contemporary Indigenous environmental justice struggles, i.e. the "disproportionate impacts due to the environmental degradation of development and resource extraction, practices such as bioprospecting (or biopiracy) and the patenting of indigenous knowledge for corporate profit, and the militarization and violence that comes with such development" (Schlosberg 84). Silko has stated that biopiracy is an often forgotten, but fundamental part of imperialism anywhere: "You have the Conquistadors, the missionaries, and right with them were the plant collectors" (qtd. in Arnold 3). Gardens in the Dunes includes the character of Edward Palmer, a scientist who has turned into a profitdriven plant smuggler and curiosities trader. The novel contrasts his bio-colonial smuggling business with the intercultural alliances and the exchange of seeds via gift giving that evolve around Indigo as a friendly visitor in Europe. Besides the status of the trader, the type of product determines the ethics of exchange (Barilla 167); Indigo's realization that "seeds must be among the greatest travelers of all" (Silko, Gardens 291) positions natural dissemination and voluntary sharing in stark contrast to the example of Palmer's attempt to smuggle stolen citrus cuttings as commodities.

Silko's novel implicitly contrasts the guiding principles of imperialism and cosmopolitics. Imperialism is discussed with focus on colonialism in the Southwest, particularly the confinement of Native Americans to reservations and the construction of a canal from the 
Colorado River to Los Angeles, but also in regard to East Coast imperial nostalgia and global biopiracy. Silko uncovers genocidal implications as deeply connected with the non-Native perception and treatment of the natural environment as wilderness and resource for exploitation. While Silko integrates the motif of a garden as a colonial tool (Gemein 239-240), she also trumps the image of imperial gardening by using a series of gardens echoing the principles for a transnational decolonization movement and cosmopolitical practice.

The geographic focus point in the novel is an Indigenous Colorado River garden - a space of community and of spiritual and natural sustenance. As I have discussed earlier (2013), the garden is shaped by the concept of sacred ecology that encompasses ecology and spirituality, posing humans as part of and partner within nature; values and ethics derive from the necessity of empirical knowledge and reciprocity between humans and other natural counterparts to create an inclusive, holistic community. Surrounded by floodplain terraces with amaranth, beans, corn, squash, sunflowers, datura, and melons, Sister Salt and Indigo learn how to tend to the garden, to be curious about new plants and their uses, and to collect seeds. Their grandmother educates them about the unreliability and fragility of mankind's power: "Old Sand Lizard [the culture hero] insisted her garden be reseeded in that way [via animal fertilizers] because human beings are undependable; they might forget to plant at the right time or they might not be alive next year" (Silko, Gardens 15). The global environmental crisis of today echoes an even broader human unreliability and irresponsibility in regards to participating in sustainable ecological processes.

The science and values transmitted by oral tradition and the interactive co-existence with animals are depicted as the core of the Sand Lizard family's lives. Yet personhood not only extends to animals and includes more complex beings, such as the Colorado River and its 
riparian plants. The construction site at the dam and the canal funneling water to Los Angeles impress a catastrophe on the Indigenous girls' minds.

Sister was shocked at the destruction she saw below: the earth was blasted open, the soil moist and red as flesh. The construction workers appeared the size of flies crawling over the hills of clayish dirt. The river had been forced from her bed into deep diversion ditches, where her water ran angry red. Big earth-moving machines pulled by teams of mules uprooted groves of ancient cottonwood trees. (Silko, Gardens 211)

This passage ascribes the river a female identity. The reader may associate the torn, flesh-like soil with a wounded body. The flies allude to decay, and the uprooted groves represent death. In short, the passage describes the site of murder with a body covered in figurative blood, lying unprotected from flies and further mutilation. The image is further supported by roots of ripped and disposed trees that "reached out plaintively like giant skeleton hands" (216). The river appears as a complex being with a "body" that consists of more than a single organic entity, incorporating animate and inanimate matter in its interspecies existence.

The younger sister Indigo perceives the river in the same way when seeing the newly built dam and its surroundings.

The river was trapped, and only a narrow stream, muddy red, flowed south. The river was stripped naked; all its willows and tamarisks were gone, its red clay banks scraped; and exposed piles of white skeletons of cottonwood trees dotted the swaths of scraped red earth. (394)

Here, the choice of verbs and the emphasis on the color red again allude to an abused body, and the "piles of white skeletons" reemphasize the image of wasteful death. Both trees and river contribute to the composite identity of the riparian habitat. This impression is supported by anthropomorphic allusions that support the concept of sentience. The reader likely envisions the damming and channeling of the river as a case of abuse and murder of a sentient being. But the point of cosmopolitics is not to anthropomorphize the environment. Multinatural ontologies do 
not rely on notions of personhood as much as anthropocentric ones. However, Silko's images function as a bridge that eases readers who are ignorant of cosmopolitical understandings into a sense of meaningfulness in extended personhood, including interspecies being and animateinanimate connections. The ultimate goal of cosmopolitics is to liberate the mind from insisting on personhood as a basis for agency, recognition and representation. In fact, Schlosberg argues that the four aspects of environmental justice - distributional equity, recognition of status, participation and procedural justice, and community functioning — can also be used for ecological justice because of the sentience, agency, and physical capabilities of nonhuman nature (229-263). Recognition derives from the notion of status as indicator for integrity. Injustice, then, can be detected based on measurable status injury. The above example of the Colorado River illustrates such a case of injured community functioning and status and the absence of recognition and participation or representation, which the sisters recognize as such. The above passages and other examples (Gemein 231-338) demonstrate that Sister Salt and Indigo perceive a cosmopolitical world very different from that of the compassionate Western women they meet, even though they can somewhat relate to each other's perspectives.

As a consequence of such multispecies and multinatural considerations cultural recognition and community functioning — two principles of environmental justice — are at the core of Silko's cosmopolitical vision. She pairs the cultural heritage and contemporary existence of a Native American community with the layered cultural and religious heritage in specific European places. Thereby she undermines the notion of a relatively homogenous, Christianity-based Western culture and stresses local cultural legacies. In fact, Silko stated in an interview: "As hard as Christianity tried to wipe it [old spirits] out, and tried to break that connection between the Europeans and the earth, and the plants and the animals - even though they've been broken from 
it longer than the indigenous people of the Americas or Africa — that connection won't break completely" (qtd. in Arnold 6). Silko's emphasis on deep time considerations of local history reflects the same idea of identity formation and decolonizing thought that Ray has pointed out in her analysis of Silko's Almanac of the Dead, that is a "prenational (as opposed to transnational) ethic of place" (7). In her appeal to maintain a strong awareness for local particularities in transnational thinking, Ray argues that "a temporally long view of injustice is perhaps more fruitful to really challenging Western environmental paradigms than a geographically expansive analysis" (18). Silko explores the long-term cultural heritage in specific locales and implies that just as the mythical and the present timescapes are thought of as concurrent or coinciding in Indigenous paradigms, such synchronism may also be found elsewhere. The effect is an outline of opportunities for a decolonization of Europeans based on cultural resources from within their own cultural heritage, especially drawing from the pre-Christian, pre-Roman period.

The character situated in England, Aunt Bronwyn, lives in an old Norman abbey's cloister with kitchen gardens and a pasture for aboriginal white cattle, which had been considered sacred in earlier times. She studies and lives by the ongoing reverence of local Celtic, pre-Christian Roman, medieval, and Christian folklore, for instance the popular belief that petroglyphs in a Neolithic stone ring and burial site are the eyes of Mary, the Christian Mother of God (Silko, Gardens 264), as well as her knowledge of Western science. She believes in fundamental principles of sacred ecology — the interdependencies between plant, animal, and human components of the land, the presence of magical components, and the value of reciprocal care and respect. For instance, she actively participates in protecting old groves and stone formations from development as it is said that the "stones and groves housed the 'good folk,' the spirits of the dead" (252). She also cares for a herd of white cattle that at times even wanders into her house 
$(136,239)$. After a rainy season, the house is flooded by the nearby river, and Silko writes about Bronwyn, "If plants and trees had individual souls, then Aunt Bronwyn decided to acquaint herself with as many different beings as possible" (242). There is a mutual understanding and an extended, interspecies community, without exclusively human spaces.

A similarly fascinating blend of historically accumulated cultural heritage can be found in the Italian gardens of Bronwyn's friend Laura. Her gardens serve to hybridize the African gladiolus and as a living exhibit for nature-oriented, European tribal art, including an old Moorish fountain, half-buried 19th century sculptures of antique mythology, and a several thousand years old Macedonian fertility sculpture. Laura has collected pre-Roman, European stone and terracotta figures, sculptures of human-animal symbolism, e.g. of human-snake beings, representing a metaphysical union of humans and other animals. Laura decides that the figures "must have fresh air and sunshine, not burial in a museum" (Silko, Gardens 294). Though housed in outside gardens in the dry months, they are carefully wrapped and prepared for a winter sleep inside. As James Barilla has pointed out, Laura's decision echoes a link between biological and cultural diversity; not only plant and animal species have life, but also cultural artifacts (166). The role and meaning of the plants for the Indigenous girls, the white cattle for Bronwyn, and the artwork for Laura are all similar.

Each of the above mentioned gardens is a literal "sanctuary" (Silko, Gardens 17) for various beings, functions as a source of spirituality and as such may be considered an inhabited and managed sacred place beyond its identity as someone's home. The inherent diversity of these gardens harmonizes because it is consistent with fundamental ethics of reciprocity and kin-like relationships and illustrates environmental justice principles. Though the garden caretakers in the novel are socially and geographically isolated, their respective worldviews are interlocked and 
the women forge lasting alliances that facilitate comprehensive decolonization - a change of mind from within and among both colonizing and colonized peoples. Moreover, by making the individual, local, and long-term temporal aspects of an implicitly transnational decolonization movement the focus of her novel, Silko suggests that ecological recovery and self-determination across the world is bound to each subject's home territory and a loose network of the likeminded. Such a vision of alliance promotes a pluralism that assumes equality among humans and the adaptive maintenance of ethnic identities and local particularities. In conclusion, Silko's creative, anticipatory rendering of a locally rooted, transnational decolonization movement of emerging cosmopolitical practice in the year 1900 may inform how and why cosmopolitics could become part of activist environmental justice discourse today.

\section{Women Leaders, Environmental Justice, and Religious Reorientation}

Within a framework of applied cosmopolitics, Silko's focus on female protagonists and spirituality in Gardens in the Dunes is not coincidental. Since neoliberal globalization is a legacy of patriarchal imperialism, it is not surprising that today's environmental justice struggles are carried largely by women, at times providing up to ninety percent of active membership in respective organizations and sixty percent of leadership in people-of-color organizations (Stein 2). Rachel Stein describes these women as "vigilant caretakers" (4) who support movements steadily on a day-to-day basis and work against institutionalized discrimination based on gender, ethnicity and class. A well-known example is the Canadian First Nations, yet increasingly global, Idle No More movement and its exemplary female leadership, which strives for "healthy, just, equitable and sustainable communities" ("The Manifesto" n.pag.) through the recognition of traditional knowledge, treaties, and self-determination. Bonnie Clairmont (HoChunk) states, "I'm 
reminded of how Indian women are strong because we protect our treaty rights, grandmother earth, resources, our children and our people," and writer Harsha Haila, who quotes Clairmont, represents this activism as a manifestation of Indigenous feminisms (Haila n.pag.).

Some of Silko's female characters illustrate such women-led, community-focused, daily activism. The Sand Lizard girls, Bronwyn, and Laura live in relative isolation and may not be members of a community-based movement, but they are charismatic individuals whose personal, cosmopolitical stories and choices contribute to collective organizing as inspiring examples. Contemporary real-world examples of such sharing of individual stories are Silko's memoir The Turquoise Ledge (2010), Linda Hogan's Dwellings (1995), many public talks by Winona LaDuke, and contributions by many other activists. In fact, the fictional characters' stories are similar to those contemporary environmental justice activists. Interviewing Native American and Hispanic women activists in New Mexico, Prindeville has found that they have often begun their participation in politics because of personal experiences (99), similar to the individualistic motivation that characterizes the women in the novel. Prindeville further remarks that her interviewees share the goals of preserving cultural practices, community health, and empowerment (98), which also is at the core of the women's organizing in Silko's novel. The fictional characters display the intellectual effort, compassion, and responsible action needed for the development of cosmopolitics and ecological citizenship, including biocultural diversity conservation and decolonization. The phenomenon of today's women-focused cross-cultural networks such as the Women's Earth Alliance (WEA) corresponds to the efforts described in the novel. In 2008, the WEA Southwest Environmental Justice Initiative sponsored visits between women lawyers and Native American women grassroots leaders in Indian Country. The visitors learned from and about the local Native communities and in response provided the services that 
were needed. They experienced a rare chance to learn not only about facts and numbers, but about cultural perspectives and values, especially spiritual aspects ("Womens [sic] Earth Alliance Southwest Environmental Justice Initiative" n. pag.).

Native American women grassroots leaders have pointed at the significance of spiritual elements in environmental, or better cosmopolitical, beliefs (Prindeville 103), which stems from the place-based, relational characteristics of Indigenous cultures. Bagele Chilisa states about Indigenous spirituality that it "can be viewed as a connection to the cosmos so that any exercise that increases connection or builds relationships is spiritual and ceremonial in nature" (114). Wildcat reaffirms this point stating, "Ecological pluralism, with some notable exceptions, explains our [Indigenous] religious diversity" (57). In Dwellings (1995), Hogan admonishes her readers: "Here is a lesson: what happens to the people and what happens to the land is the same thing" (89), and calls for a renewed spirituality with respect for all organisms and a healing language, which she circumscribes as "searching for an ecology of mind" (60). Therefore, Prindeville points out that recognizing the "interconnectedness among Native spirituality, environment, and tribal sovereignty" (103) is a necessary key toward fruitful communication.

Silko picks up the thread of spirituality, ethics, and self-determination in her novel and envisions how such perceptions could be shared with non-Natives. She approaches the possibility of a rediscovered spirituality by creatively interweaving ideas of American Transcendentalism and the above-mentioned explorations of European cultural heritage. Though Silko never mentions Transcendentalism in her novel, she has stated in an interview that she sees the movement as the first step in mainstream American culture toward a change of perception concerning the environment and human-nature relationships: "The Europeans come to this land, and the old prophesies say, not that the Europeans will disappear, but the purely European way 
of looking at this place and relationships. So the American Transcendentalists, they're the first important sign that this is already underway" (qtd. in Arnold 18). Per Silko, American Transcendentalism has initiated an understanding of connections and interdependencies that place-based tribal cultures, both in the Americas and in pre-imperial Europe, had long since understood and had shaped in worldviews characterized by the inherently cosmopolitical concept of sacred ecology.

The diversity and interaction between cultures, however, requires more attention and care than American Transcendentalism with its imperial context had to offer. Inspired by Margaret Fuller's compassion-driven approach to Transcendentalism and journey toward selfdetermination (Arnold 17), Silko creates female characters who display a deep compassion that provides opportunities for inter-human and multispecies understanding not easily available in the otherwise male-oriented American Transcendentalism. In Gardens in the Dunes, Bronwyn and Laura's approaches move beyond Transcendentalism by combining it with an explicit search for what Deborah Miranda calls a "white, European indigeneity" (142) — the notion echoes Adamson's discussion of the Zapatista slogan ¡Todos Somos Indios! ("¡Todos Somos Indios!" 56) — that in this case is nourished by layered cultural experience and religious synthesis. While Bronwyn connects Celtic, Roman, and Christian religious teachings with science, Laura traces pre-Christian Mediterranean fertility cults. Finally, Hattie Palmer, a disoriented ex-academic, slowly rediscovers her emotions, spirituality, and compassionate ability for self-determination and advocacy. She lives out a potential Silko may have seen in Fuller's approach to Native America, had Fuller not been so influenced by the dominant ideologies of her time (Gemein 75$87,253-257)$. 
Compassion combined with transcendental awareness offers opportunities for an inclusive spirituality, and Silko poses the culturally syncretistic Ghost Dance movement against transAtlantic imperial trade and exploitation networks. The novel begins and ends with a Ghost Dance ceremony. During the first one, Sister Salt and Indigo lose their mother, and Indigo sees her voyage to Europe as part of her search for the Messiah's family and her mother. Motifs and spiritual references to the Ghost Dance in connection to other religious traditions permeate the novel. The second ceremony is a spiritual, mental, and emotional turning point for Indigo's host mother Hattie Palmer. Overall, the Ghost Dance serves as an exemplary, pluralist gateway to cosmopolitical practice in the novel. David Moore writes in his discussion of the role of the hybrid, "Gardens is a novel of botanical and cultural syncretism" (96). Indeed, Silko does not present hierarchized hybridization as "the project of power to dominate" (Moore 99), but rather contrasts it with an organically growing, pluralist and equality-oriented global network. The highly integrative and adaptive Ghost Dance provides a paradigm-shifting framework in which intercultural communication, material and knowledge exchange and alliances take place. Yet Silko states, "Gardens in the Dunes really is about now. It all connects together and it gives you a psychic and spiritual way to try to live within this" (qtd. in Arnold 21). Like Hogan, Silko insists on spiritual aspects and therefore creatively re-interprets the Ghost Dance as a hybrid spiritual movement of the kind that could produce necessary ontological and epistemological changes to counter imperialist, neoliberal ideology. She claims, "Everyone has to agree. And the retaking of the Americas is not literal, but it's in a spiritual way of doing things" (qtd. in Arnold $10)$.

Silko's most surprising choice in treating the Ghost Dance in Gardens in the Dunes, however, is her treatment of a protagonist's quest for religious and philosophical understanding, as well as 
for cultural identity. This core element of indigenism in many Native American novels usually features an Indigenous and/or mixed-blood literary protagonist, but Silko puts a non-Native academic in that place. Indigo's host-mother Hattie Palmer is lonesome and disoriented after the male faculty at Harvard prevented her from graduating with her supposedly heretical thesis on "The Feminine Principle in the Early Church" (Silko, Gardens 100-101). Men and women equally reject her for her academic efforts and label her as hysterical when the circumstances make her ill. But during the travels with Indigo, Hattie discovers spiritual power through dreams and supernatural encounters that connect all stations of her travel and the different cultures and religious beliefs she learns to know. All events lead her toward sensuality, closeness to the natural environment and increased attention toward intuition and the subconscious. After a neardeath experience and a revelation at the margins of a Ghost Dance ceremony, she liberates herself from others' expectations and decides to live in England, her ancestors' homeland. Silko's unconventional choice for an Anglo-American vision quest illustrates that cultural revitalization among oppressed communities alone is insufficient and that the larger, Western society also displays an urgent need for alternative stories and visions. Penetrating the novel in a subtle, but powerful way, the Ghost Dance appears as a counter-movement to Euro-American imperialism. Silko even equips the Ghost Dance with a transnational focus that connects the Biblical Middle East with Europe and the Americas, as well as Indigenous with non-Native protagonists. Thus she rewrites not only James Mooney's well-known anthropological account of the Ghost Dance (1892-93), but also the story of Christianity as a world religion. While Mooney tries to demystify Wovoka and to present the Ghost Dance as a non-violent movement toward civilization and Christianity, Silko reclaims the supernatural elements, connecting Wovoka and Jesus as prophets. A radiant light, birds, wind, and snow are indicators of their presence and provide the 
ceremony with a strong component of non-human agency. Indigo traces the Messiah's tracks in Europe based on the appearance of birds and rocks, Hattie repeatedly encounters a fulfilling bright light, and both find signs of the Virgin Mary's presence in various places. The appearance of the Holy Mother on a school wall in Corsica leads to a showdown between protesting Church representatives and believers of such popular elements of Catholicism. In this episode, Silko indicates that institutionalized religion is too entangled in socio-political power hierarchies to truly maintain its initially inclusive and compassionate mission. Combining the gnostic tradition, pre-Christian European religions, Indigenous American religions, and Western scientific traditions Silko writes against religious ideas of purity and dogma and stresses interconnection and diversity that both are key features of cosmopolitics.

Furthermore, when described through Indigenous insider perspectives rather than an authoritative anthropological voice, the Ghost Dance as a religious revitalization movement is a form of self-representation in response to constructed representations by outsiders. Silko's storytelling subverts and hybridizes various master narratives. As Gerald Vizenor points out, English was a major language in the Ghost Dance, carrying "stories of endurance and tribal spiritual restoration" (227), and is subversive and healing in creative writing today. Thus Vizenor claims, "The language of tribal novelists and poets could be a literary ghost dance, a literature of liberation that enlivens tribal survivance" (ib.). The Ghost Dance in Silko's novel anticipates a global, spiritual movement that integrates recognition, community functioning, and participation in a framework of survivance, focusing on environmental and ecological justice. It allows for a plurality and ambiguity that keep the movement malleable and adaptive to local circumstances. Silko's act of literary ghost dance, in Vizenor's words, is an appeal and in some ways a manual for a decolonization and pluralization in the fashion of cosmopolitics. 
Like other works of Native American literatures, Gardens in the Dunes thus serves as a tool for sharing ideas and alternative conceptualizations, providing cross-cultural explanations via personalized examples, and offering intellectual impulses together with intuitive appeals. The novel may allow non-Native readers to better understand the significance of spirituality in environmental justice as it is stressed by contemporary Native activists. Silko further provides role models for alternative, non-imperial choices and philosophies, environmental justice, and nurturing alliances, i.e. just those larger sets of concerns indicative of global movements today. In conclusion, such widely published and translated Native American novels may well function as a medium for sharing cosmopolitical understandings, whether or not cosmopolitics is expressly identified as such.

\section{Growing Seeds of Intellectual Integration}

Especially in the face of Western cultural constructs, such as "environmentalism" as the only perceived spectrum of human-nature relationships and the reductive notion of the "ecological Indian" or "noble savage," it is difficult to converse about multispecies relationships in predominantly colonial languages, despite their creative use in the literary realm. Dealing with environmental issues and conceptualizations is more than a matter of translation and linguistic dominance. While it is appropriate to say that cosmopolitics has long been part of Indigenous political practices, it has been poorly understood outside of Indigenous communities. Those involved in environmental justice negotiations but unfamiliar with Indigenous paradigms struggle to understand relational ontologies. Despite being well-educated, many people may not be aware of their intellectual barriers and not think beyond simplified conceptualizations of a "Mother Earth." Moreover, diverse Indigenous terms, concepts and definitions stand in a 
dynamic relationship. While Native American literatures certainly contribute to a better understanding, changing communication and thought patterns in transnational movements also requires improved terminology. The term cosmopolitics — in addition to already used terms, such as (eco-)cosmopolitanism - is a promising tool for improved thinking and negotiation. It will not solve all communicative problems, but it will enhance a more complex consideration of options. Using the term to identify existing philosophical and political perspectives and to transform them into concise arguments and proposals is desirable as a potential way to change the discourse.

In disseminating the term and concept of cosmopolitics to those most actively involved, academia can play a crucial role. Due to their interdisciplinary nature and their dedication to social critique and activism, Native American and Indigenous Studies in conjunction with the Environmental Humanities are demonstrating their potential as brokers for a paradigmatic shift within Western discourse by building on the concepts of biocultural diversity and cosmopolitics. However, the divide between academic and real-world political discourses still has to be overcome, not only by teaching respective course work and academic publishing, but by more involvement of academics in communities, grassroots movements and NGOs. Given their potential of critical research and analytical skills, academics can serve as conceptual translators, interpreters, and mediators, complementing and validating the work of authors and activists, but they would have to do so beyond the realm of academia. Scholars have so far played an insufficient role as cultural brokers of cosmopolitics because the term is largely unknown outside of academia. If the idea of a scholar-activist is a serious one, it must manifest itself not only in academic publishing, but for instance in creating freely available TED-Technology, Entertainment, Design—-talks for the web ("TED: Ideas Worth Spreading"), targeting popular science magazines, and applying other media that can serve intellectual outreach. If science 
communication and scientifically based activism function well, there is also hope that visual and literary artists as well as filmmakers might pick up on such a new and inspiring key word as cosmopolitics.

At the confluence of Western science and Indigenous paradigms, "cosmopolitics" as a clarifying name for an old phenomenon can lay a foundation for intellectual integration. By using, applying, and explaining cosmopolitics, it can become a new story, a growing seed of communication that changes the discourse within and around existing movements. And if seeds are indeed "among the greatest travelers of all" (Silko 291), it is all about whom one tells what story. Louis Owens' words are encouraging: "Stories, I learned very early, make the world knowable and inhabitable. Stories make the world, period" (210). If stories make, and if necessary, re-make the world, then the Native American literature at hand is revolutionary. The example of Silko's novel emphasizes that cosmopolitics is for everyone and, indeed, has to be for everyone if it is supposed to make a difference. She expands the cosmopolitics association to a global Indigenous movement by calling upon the recognition and validity of European tribal traditions and the need for decolonization of the colonizer as part of a larger paradigm shift and spiritual reconsideration. The example of Gardens in the Dunes shows that Indigenous literatures can provide pathways to complex intercultural discussions on paradigms, concepts, and related language use. Scholar-activists can provide such intercultural bridges for intellectual integration, helping others to individually cultivate the seeds of cosmopolitical communication. 


\section{Works Cited}

Adamson, Joni. "Source of Life: Avatar, Amazonia, and an Ecology of Selves." Material Ecocriticism. Ed. Serenella Iovino and Sergil Oppermann. Bloomington: Indiana University Press, 2014. 253-268. Print.

---. "Cosmovisions: Environmental Justice, Transnational American Studies and Indigenous Literature." The Oxford Handbook of Ecocriticism. Ed. Greg Garrard. New York: Oxford University Press, 2014. 172-187. Oxford Handbooks Online. Web. 3 July 2015.

---. "Indigenous Literatures, Multinaturalism, and Avatar: The Emergence of Indigenous Cosmopolitics." American Literary History 24.1 (Spring 2012): 143-162. Project Muse. Web. 12 Mar 2012.

---. "'¡Todos Somos Indios!' Revolutionary Imagination, Alternative Modernity, and Transnational Organizing in the Work of Silko, Tamez, and Anzaldúa." Journal of Transnational American Studies 4.1 (2012): 1-26. eScholarship, University of California, 2013. Internet resource.

---. American Indian Literature, Environmental Justice, and Ecocriticism: The Middle Place. Tucson: U of Arizona P, 2001. Print.

Arnold, Ellen. "Listening to Spirits: An Interview with Leslie Marmon Silko." Studies in American Indian Literatures 2nd ser. 10.3 (1998): 1-33. Print.

Barilla, James. "Biological Invasion Discourse and Leslie Marmon Silko's Gardens in the Dunes." Reading Leslie Marmon Silko: Critical Perspectives Through Gardens in the Dunes. Ed. Laura Coltelli. Pisa: Pisa UP, 2007. 165-176. Print.

Cadena, Marisol de la. "Indigenous Cosmopolitics in the Andes: Conceptual Reflections beyond 'Politics'." Cultural Anthropology 25.2 (2010): 334-370. JSTOR. Web. 07 Nov 2011. 
Chilisa, Bagele. Indigenous Research Methodologies. Los Angeles: Sage, 2012. Print.

Deloria, Vine, Jr. "If You Think About It, You Will See That It Is True." Spirit and Reason: The Vine Deloria, Jr., Reader. Ed. Barbara Deloria, Kristin Foehner and Sam Scinta. Golden: Fulcrum Publishing, 1999. 40-60. Print.

Gemein, Mascha N. "Multispecies Thinking from Alexander von Humboldt to Leslie Marmon Silko: Intercultural Communication Toward Cosmopolitics." Order No. 3560821. The University of Arizona, 2013. Ann Arbor: ProQuest. Web. 1 Nov 2013.

Haila, Harsha. "Indigenous Women: Never Idle." 28 June 2013. Feminist Wire. Web. 25 Oct 2013.

Heise, Ursula K. Sense of Place and Sense of Planet: The Environmental Imagination of the Global. Oxford: Oxford University Press, 2008. Print.

Hogan, Linda. Dwellings: A Spiritual History of the Living World. New York: W.W. Norton \& Company, 1995. Print.

Latour, Bruno. "Whose Cosmos, Which Cosmopolitics? Comments on the Peace Terms of Ulrich Beck." Common Knowledge 10.3 (Fall 2004): 450-462. Project Muse. Web. 21 June 2012.

---. Politics of Nature: How to Bring the Sciences into Democracy. Cambridge: Harvard UP, 2004. Print.

Miranda, Deborah. "A Gynostemic Revolution: Some Thoughts About Orchids, Gardens in the Dunes, and Indigenous Feminism at Work." Reading Leslie Marmon Silko: Critical Perspectives Through Gardens in the Dunes. Ed. Laura Coltelli. Pisa: Pisa UP, 2007. 133148. Print.

Mooney, James. 1892-93. The Ghost Dance. North Dighton: JG P, 1996. Print. 
Moore, David L. "Ghost Dancing Through History in Silko's Gardens in the Dunes and Almanac of the Dead." Reading Leslie Marmon Silko: Critical Perspectives Through Gardens in the Dunes. Ed. Laura Coltelli. Pisa: Pisa UP, 2007. 91-118. Print.

Owens, Louis. Mixedblood Messages: Literature, Film, Family, Place. Norman: U of Oklahoma P, 1998. Print.

Prindeville, Diane-Michelle. "The Role of Gender, Race/Ethnicity, and Class in Activists' Perceptions of Environmental Justice." New Perspectives on Environmental Justice: Gender, Sexuality, and Activism. Ed. Rachel Stein. New Brunswick, N.J: Rutgers University Press, 2004. 93-108. Print.

Ray, Sarah Jaquette. "Environmental Justice, Transnationalism, and the Politics of the Local in Leslie Marmon Silko's Almanac of the Dead." Journal of Transnational American Studies 5.1 (2013): 1-24. eScholarship, University of California, 2013. Internet resource.

Schlosberg, David. Defining Environmental Justice: Theories, Movements, and Nature. Oxford: Oxford University Press, 2007. Print.

Silko, Leslie M. The Turquoise Ledge: [a Memoir]. New York: Viking, 2010. Print.

---. Gardens in the Dunes. New York: Simon \& Schuster, 1999. Print.

Stein, Rachel. "Introduction." New Perspectives on Environmental Justice: Gender, Sexuality, and Activism. Ed. Rachel Stein. New Brunswick, N.J: Rutgers University Press, 2004. 1-17. Print.

Stengers, Isabelle. "The Cosmopolitical Proposal." Making Things Public: Atmospheres of Democracy. Ed. Bruno Latour and Peter Weibel. Cambridge: MIT Press, 2005. 994-1004. Print.

"TED: Ideas Worth Spreading." TED Conferences LLC. Web. 10 Sept 2013. 
"The Manifesto." Idle No More. Web. 22 Oct 2013.

Viveiros de Castro, Eduardo. "Exchanging Perspectives: The Transformation of Objects into Subjects in Amerindian Ontologies." Common Knowledge 10.3 (Fall 2004): 463-484. Project Muse. Web. 21 June 2012.

Vizenor, Gerald. "Native American Indian Literature: Critical Metaphors of the Ghost Dance." World Literature Today 66.2 (Spring 1992): 223-227. JSTOR. Web. 08 May 2012.

Wildcat, Daniel R. Red Alert! Saving the Planet with Indigenous Knowledge. Golden: Fulcrum Publishing, 2009. Print.

Women's Earth Alliance. "Women's Earth Alliance Southwest Environmental Justice Initiative." 8 Apr 2009. Web. YouTube. 9 Sept 2013. 